\title{
(6) \\ Tobacco endgame strategies: challenges in ethics and law
} OPEN ACCESS

\author{
Bryan P Thomas, Lawrence 0 Gostin
}

O'Neill Institute for National and Global Health Law, Georgetown University Law Center, Washington, DC, USA

\section{Correspondence to}

Dr Bryan P Thomas, O'Neill Institute for National and Global Health Law, Georgetown University Law Center, 600 New Jersey Avenue, NW, Washington, DC 20001, USA: bpt11@law.georgetown.edu

Received 15 October 2012 Accepted 1 March 2013
To cite: Thomas BP, Gostin LO. Tob Control 2013;22:i55-i57.

\section{ABSTRACT}

There are complex legal and ethical tradeoffs involved in using intensified regulation to bring smoking prevalence to near-zero levels. The authors explore these tradeoffs through a lens of health justice, paying particular attention to the potential impact on vulnerable populations. The ethical tradeoffs explored include the charge that heavy regulation is paternalistic; the potentially regressive impact of heavily taxing a product consumed disproportionately by the poor; the simple loss of enjoyment to heavily addicted smokers; the health risks posed by, for example, regulating nicotine content in cigarettes - where doing so leads to increased consumption. Turning to legalistic concerns, the authors explore whether endgame strategies constitute a form of 'regulatory taking'; whether endgame strategies can be squared with global trade/investment laws; whether free speech rights are infringed by aggressive restrictions on the advertisement and marketing of cigarettes.

Smoking prevalence in high-income countries has dropped considerably due to a suite of populationlevel strategies: education campaigns, warning labels, advertising restrictions, clean air laws, age limits and taxation. Low-income and middle-income countries are gradually implementing similar measures, and evidence of effectiveness is emerging. ${ }^{1}$ This progress risks stalling in doubledigit percentages, at the potential cost of a billion lives over the coming century, as established measures reach a point of diminishing returns. ${ }^{2}$

Consequently, there is growing interest in 'endgame strategies', following the full implementation of existing measures. 'Endgames' would shift regulatory focus to the supply side of the market ${ }^{3}$ : limiting nicotine content below addictive levels ${ }^{4}$; raising $\mathrm{pH}$ to un-inhalable levels ${ }^{5}$; entrusting tobacco marketing and/or supply to a nonprofit agency, mandated to drive sales down ${ }^{67}$; imposing a 'sinking lid' on the supply of tobacco available for commercial sale, driving prices upward ${ }^{8}$ and setting a generational cutoff (eg, banning sale to anyone born after 1999). ${ }^{9}$ Endgame strategies must avoid the pitfalls of alcohol prohibition-popular revolt and underground tobacco markets-and should not be implemented until prevalence is low (eg, under 15\%), governments are strongly committed and public support overwhelming. ${ }^{10}$

\section{ETHICAL TRADEOFFS IN TOBACCO ENDGAMES}

Existing tobacco controls encourage prevention and smoking cessation but respect adult autonomy while shielding others from the associated harms and costs. Autonomous decision making is the norm, notwithstanding evidence of nicotine dependence. ${ }^{11}$ Warning labels inform consumers, clean air laws protect third parties from secondhand smoke, taxes internalise the social costs of smoking, while age limits and marketing restrictions ostensibly protect minors.

Endgames depart from this paradigm. A generational cutoff, for example, would (in time) prohibit informed adults from purchasing cigarettes. Adults, even if well informed, may smoke for personal reasons-whether to alleviate anxiety, combat weight gain or simply for pleasure. In most other contexts, adults are permitted to make harmful choices that are primarily self-regarding. However, the case for paternalism-interfering with individuals' liberty to protect and promote their best interests-is particularly powerful in the case of tobacco control. It has that rare combination of being uniquely harmful to health and heavily addictive, with enormous social and economic costs to families and communities. Most adults initiate smoking as adolescents ${ }^{12}$ and now wish they could quit. ${ }^{13}$ Given this combination of harms, governments would never grant regulatory approval if cigarettes were invented today. Seen through this lens, endgames are not unjustified paternalism but the long-overdue closure of a cavernous gap in health and safety standards.

Some endgame strategies may trade the interests of already addicted smokers against the protection of future generations. Proposals to gradually lower nicotine content below the addiction thresholdsguarding younger generations from dependencymay cause already addicted adults to resort to compensatory smoking, increasing exposure to poisons and carcinogens. ${ }^{4}$

Intergenerational tradeoffs are entailed as well in proposals to raise tobacco taxes to prohibitive levels or set a sinking lid on tobacco supply. While teenagers will be deterred by price increases, addicted smokers-who are disproportionately low income-may choose to forego essentials (food, shelter and medicines) to satiate their habit. ${ }^{14}$ The intent is that decreased nicotine content and rising prices will, in the long run, motivate individuals to quit. Still, government has a duty to mitigate these costs by making tobacco cessation therapies accessible and affordable.

People often smoke as a way of coping with stress $^{15}$ - a fact that partly explains the grossly inequitable socioeconomic distribution. As governments intensify strategies to denormalise tobacco use, they will further stigmatise and isolate smokers, threatening their dignity and adding shame to already hard lives. While this may be inevitable, it remains troubling. Protecting the public's health and blaming individuals who are 
suffering may be hard to separate. However, it is government's —and all of society's-ethical responsibility to show respect and caring for smokers, even while strictly regulating their access to harmful products. ${ }^{16}$

Finally, efforts at reducing overall tobacco prevalence, if focused solely on aggregate measures, may turn a blind eye to distributional equity. Suppose that endgame strategies reduced tobacco prevalence to 5\%: higher socioeconomic classes might decline to $1-2 \%$, with double-digit prevalence among the poor, less educated or mentally ill. This would exacerbate already existing, and unconscionable, health disparities. Endgame strategies, therefore, should pay particular attention to the least advantaged, focusing on equitable distribution of benefits.

\section{LAW AS AN OBSTACLE TO TOBACCO ENDGAMES}

The law has been used as a sword and a shield in tobacco control. Litigation against 'Big Tobacco' in the USA culminated in a Master Settlement Agreement in 1998. The litigation was transformative, especially in compelling the release of documents revealing the industry's dishonesty and aggressive marketing tactics. By 2005, the WHO's Framework Convention on Tobacco Control (FCTC) enshrined tobacco control strategies into international law.

More recently, the industry has turned the tables: from Australia and the USA to Uruguay, the industry has used constitutional law, ${ }^{17}$ as well as international investment and trade agreements, ${ }^{18}$ in an effort to block tobacco controls. With their very survival at stake, it is to be expected that these legal strategies will be redeployed at the endgame stage.

\section{Property rights}

What all endgame strategies have in common is their deliberate intent to drastically reduce the economic viability of the industry. Most constitutions, as well as bilateral investment treaties, guarantee corporate property rights, requiring that state 'acquisition of property' must be on 'just terms'. That was the primary basis of the industry's suit against Australia's plain packaging legislation, although the High Court roundly rejected the claim in August 2012. ${ }^{19}$

Beyond constitutional law, many states have negotiated bilateral investment treaties that have similar guarantees not to unfairly deprive corporations of their profits. The industry has challenged Australia's plain packaging laws, as well as Uruguay's mandated health warnings, under investment treaties. ${ }^{20}$ Both cases will be decided through international arbitration. Although the outcome is uncertain, national courts and international tribunals should rule in favour of the state. In implementing tobacco control, government is exercising the sovereign authority to protect the public's health.

Endgame strategies, even more than graphic warnings, will deprive the tobacco industry of vast corporate profits. It is conceivable that courts would balk at such a complete deprivation of earning potential. Nevertheless, government should be entitled to drastically limit, even bar, the industry from profiting by marketing highly dangerous products.

\section{Trade and intellectual property rights}

Multinational tobacco companies will also pressure governments to challenge endgames under international trade agreements. Multiple legal arguments are available to the industry, including trade discrimination and deprivation of intellectual property. In April 2012, for example, the WTO Appellate Body ruled that the USA discriminated against Indonesia by banning cloveflavoured cigarettes. ${ }^{21}$ The 2009 US Family Smoking Prevention and Tobacco Control Act (FSPTCA) prohibited all flavoured cigarettes but exempted menthol pending an FDA review. The Appellate Body found that clove and menthol cigarettes are 'like products'. To comply with the ruling, the USA would either have to allow clove cigarettes onto the market or end the menthol exemption.

Perhaps the more troublesome trade rule requires states to respect intellectual property, including trademarks. The Ukraine and other states, for example, are challenging Australia's plain packaging law under this theory. Trade law specifically allows states to protect the public's health, but governments must do so based on sound science and without unfair discrimination. Endgame strategies would have to meet this test, demonstrating that they significantly improve the public's health in ways that are no more trade restrictive than necessary to achieve their goals.

\section{Commercial speech}

Constitutions frequently safeguard the right to free expression. Most constitutional courts reserve these safeguards for political, artistic and social discourse. Yet a few, notably the US Supreme Court, have developed commercial speech doctrines. The FCTC, at the insistence of the USA, specifically preserved states' rights to refrain from tobacco control where required under their constitutions. The industry, for example, has successfully challenged Massachusetts regulations restricting tobacco advertising and sales, finding that the limits were more extensive than necessary. ${ }^{22}$ More recently, a US appellate court struck down FDA-mandated graphic health warnings as a form of 'compelled commercial speech'. ${ }^{23}$ (However, another federal appeals court upheld the warnings as valid in principle-the actual images proposed had not yet been released at the time of trial-suggesting the matter is destined for the Supreme Court. ${ }^{24}$ )

\section{Political speech}

Endgame strategies require a hospitable political climate. Lawmakers in New South Wales (Australia) have attempted to foster this, by banning political donations from tobacco entities. ${ }^{25}$ In the USA, attempts to limit Big Tobacco's influence on lawmakers and public opinion are bound to run into First Amendment challenges-particularly in light of the Supreme Court's 2010 decision in Citizens United v. Federal Election Commission, which afforded constitutional protection to corporations' political contributions. ${ }^{26}$

\section{THE FUTURE OF TOBACCO ENDGAMES}

Tobacco endgames will face vehement political opposition, fuelled by industry lobbying. Beyond politics, public health advocates have to think through the ethical minefields and inevitable legal challenges. The political and legal battles, however hard, are worth the cost, given the enormous benefits of public health and economic productivity conferred by a tobacco-free society.

Contributors The two authors contributed equally to the research and writing of this article.

Competing interests None.

Provenance and peer review Not commissioned; externally peer reviewed.

Open Access This is an Open Access article distributed in accordance with the Creative Commons Attribution Non Commercial (CC BY-NC 3.0) license, which permits others to distribute, remix, adapt, build upon this work non-commercially, and license their derivative works on different terms, provided the original work is properly cited and the use is non-commercial. See: http://creativecommons.org/ licenses/by-nc/3.0/ 


\section{REFERENCES}

1 Abascal W, Esteves E, Beatriz G, et al. Tobacco control campaign in Uruguay: a population-based trend analysis. Lancet 2012;380:1575-82.

2 Warner KE, Mendez D. Tobacco control policy in developed countries: yesterday, today and tomorrow. Nicotine Tob Res 2010;12:876-87.

3 Callard C, Collishaw NE. Exploring vector space: overcoming resistance to direct control of the tobacco industry. Tob Control 2012;21:291-2

4 Benowitz NL, Henningfield JE. Establishing a nicotine threshold for addiction. N Engl J Med 1994;2:123-5.

5 Proctor RN. Golden holocaust: origins of the cigarette catastrophe and the case for abolition. Berkeley, CA: University of California Press, 2011:553.

6 Borland R. A Strategy for controlling the market of tobacco products: a regulated market model. Tob Control 2003;12:374-82.

7 Callard C, Thompson D, Collishaw N. Transforming the tobacco market: why the supply of cigarettes should be transferred from for-profit corporations to non-profit enterprises with a public health mandate. Tob Control 2005; 14:278-83.

8 Thomson G, Wilson N, Blakely T, et al. Ending appreciable tobacco use in a nation: using a sinking lid on supply. Tob Control 2010;19:431-5.

9 Khoo D, Chiam Y, Ng Priscilla, et al. Phasing out tobacco: proposal to deny access to tobacco to those born from 2000. Tob Control 2010;19:355-60.

10 Thomson G. What are the elements of the tobacco endgame? Tob Control 2012:21:293-5.

11 Levy N. Autonomy and addiction. Can J Philos 2006;36:427-47.

12 U.S. Department of Health and Human Services. Preventing tobacco use among youth and young adults: a report of the surgeon general. Atlanta, GA: Department of Health and Human Services, Centers for Disease Control and Prevention, National Center for Chronic Disease Prevention and Health Promotion, 2012:21-9.

13 Centers for Disease Control and Prevention. Quitting smoking among adultsUnited States, 2001-2010. Morb Mortal Wkly Rep 2011;60:1513-19.
14 Farrelly MC, Nonnemaker JM, Watson KA. The consequences of high cigarette excise taxes for low-income smokers. PLOS ONE 2012;7:e43838.

15 McKee SA, Sinha $\mathrm{R}$, Weinberger $\mathrm{AH}$, et al. Stress decreases the ability to resist smoking and potentiates smoking intensity and reward. J Pharmacol 2011;25:490-502.

16 Bayer R, Stuber J. Tobacco control, stigma and public health: rethinking the relations. Am J Public Health 2006 96:47-50.

17 Cabrera OA, Gostin LO. Human rights and the framework convention on tobacco control: mutually reinforcing systems. Int J Law Context 2011;7:285-303.

18 Crosbie E, Glantz SA. Tobacco industry argues domestic trademark laws and international treaties preclude cigarette health warning labels, despite consistent legal advice that the argument is invalid. Tob Control 2012;1-9. doi:10.1136/ tobaccocontrol-2012-050569

19 JT International SA v Commonwealth of Australia; British American Tobacco Australasia Limited \& ORS v Commonwealth of Australia (15 August 2012).

20 Taylor A. Plain Packaging: Fighting the Chill of Investment Treaties. JURIST_Forum, 7 Dec 2011. http://jurist.org/forum/2011/12/allyn-taylor-tobacco-suit.php (accessed Sep 2012).

21 WTO. United States - measures affecting the production and sale of clove cigarettes. Report of the Appellate Body, WT/DS406/AB/R, April 2012.

22 Lorillard Tobacco Co. v. Reilly, 121 S. Ct. 2404 (2001).

23 R.J. Reynolds Tobacco Co. v. U.S. Food and Drug Administration, _ F. 3rd _ (D.C. Cir. 24 August 2012)

24 Discount Tobacco City \& Lottery, Inc. v. United States, 674 F. 3rd 509 (6th Cir. 2012).

25 New South Wales Parliament. Election Funding and Disclosures Amendment Act 2010 No 95. Sydney: New South Wales Parliament, 2010.

26 Citizens United v. Federal Election Commission, 558 U.S. 310 (2010). 